\title{
Relation between concentrations of metronidazole and Bacteroides spp in faeces of patients with Crohn's disease and healthy individuals
}

\author{
AUD KROOK,*† BJÖRN LINDSTRÖM, J JAN KJELLANDER,* \\ GUNNAR JÄRNEROT, $\dagger$ LENNART BODIN §
}

From the * Department of Clinical Microbiology and Department of Internal Medicine, $\dagger$ Division of Gastroenterology, Central County Hospital, Orebro, and $\ddagger$ National Board of Health and Welfare, Department of Drugs, Division of Clinical Drug Trials, Uppsala, and §Department of Statistics, University of Orebro, Sweden

SUMmaRY Nine patients with Crohn's disease and six healthy individuals were given $400 \mathrm{mg}$ metronidazole twice daily and the concentration was measured in plasma and faeces 6 to $8 \mathrm{~h}$ after intake. Quantitative and qualitative bacteriological examinations were performed before and during treatment. The concentrations of metronidazole in plasma varied between 5 and $30 \mathrm{mg} / \mathrm{l}$ as measured by liquid chromatography (LC) and between 3 and $20 \mathrm{mg} / \mathrm{l}$ as measured by a bioassay (BA) method. There were no significant differences between the results of the two methods in patients but compared with BA the LC values were regularly lower in the healthy subjects.

Metronidazole was detected in the faeces of most patients. These findings coincided with a significant reduction of Bacteroides spp in their faeces which was not apparent in healthy individuals in whom metronidazole was not detected in the faeces. Higher faecal metronidazole concentrations were found in patients with active disease and a total colon involvement as compared with the patients with a more quiescent disease and involvement of ileum and ascending colon only.

Metronidazole was originally introduced in 19591 to treat Trichomonas vaginalis infections, and a few years later it was found to be of therapeutic value in Vincent's gingivitis. ${ }^{2}$ It was shown in the early seventies to be effective in vitro against many obligate anaerobic bacteria. ${ }^{34}$ Metronidazole has lately been used to treat abdominal as well as extraabdominal severe anaerobic infections ${ }^{5}$ and as a prophylactic for anaerobic infections in surgery. ${ }^{6}$

Ursing and Kamme (1974) reported a therapeutic effect of metronidazole in Crohn's disease. ${ }^{7}$ This has been a matter for dispute by other authors ${ }^{8}{ }^{9}$ but in a recently-finished controlled study in Sweden, metronidazole was shown to be at least as effective as sulphasalazine in active Crohn's disease (Ursing et al., unpublished observations). The mode of its action in these patients is unclear. However, there was a statistically significant reduction of Bacteroides spp during metronidazole treatment which could not be demonstrated in healthy individuals. ${ }^{1011}$
There are few studies on the concentrations of metronidazole in the human faeces. The concentrations obtained were low or not measurable in studies on healthy individuals ${ }^{12}$ or in connection with colon surgery, metronidazole and neomycin treatment. ${ }^{13}$ To find an explanation of the different effects on the faecal flora in healthy individuals and patients with Crohn's disease we decided to investigate the concentrations of metronidazole in plasma and faeces during treatment and relate these findings to possible changes on the faecal flora.

\section{Material and methods}

SUBJECTS AND DESIGN OF THE STUDY Nine patients (six women and three men aged between 12 and $43 \mathrm{yr}$ ) with a diagnosis of Crohn's disease were included (Table 1). The diagnosis was based on current clinical, radiological, and histopathological criteria. All patients except case 4 had active disease with serum-orosomucoid value $>1.55$ $\mathrm{g} / \mathrm{l}$ (normal range: $0 \cdot 7-1 \cdot 3 \mathrm{~g} / \mathrm{l}$ ) and all of them, except cases 4 and 5 had a Crohn's disease activity 
Table 1 Pretreatment characteristics of the patients

\begin{tabular}{|c|c|c|c|c|c|c|c|}
\hline \multirow[t]{2}{*}{ Case No } & \multirow[t]{2}{*}{ Sex } & \multirow[t]{2}{*}{ Age $(y r)$} & \multicolumn{3}{|c|}{ Site of disease and extent $(m)^{*}$} & \multirow[t]{2}{*}{$C D A I$} & \multirow[t]{2}{*}{$S$-oroso $(g / l)$} \\
\hline & & & Small bowel & Colon & Rectum & & \\
\hline 1 & $\mathbf{F}$ & 25 & 0.2 & asc & - & 283 & $2 \cdot 6$ \\
\hline 2 & $\mathbf{F}$ & 18 & $0 \cdot 1$ & asc & - & 203 & $1 \cdot 8$ \\
\hline 3 & $\mathbf{F}$ & 43 & $0 \cdot 1$ & asc & - & 300 & $4 \cdot 5$ \\
\hline 4 & $\mathbf{F}$ & 32 & $0 \cdot 2$ & asc & - & 73 & $1 \cdot 4$ \\
\hline 5 & $\mathbf{M}$ & 12 & 0.2 & - & present & 112 & $4 \cdot 5$ \\
\hline 6 & $\mathbf{F}$ & 24 & - & tot & - & 348 & $2 \cdot 2$ \\
\hline 7 & $\mathbf{M}$ & 37 & 0.5 & tot & present & 311 & $4 \cdot 0$ \\
\hline 8 & $\mathbf{M}$ & 27 & - & tot & present & 214 & $2 \cdot 7$ \\
\hline 9 & $F$ & 18 & 0.4 & tot & - & 281 & $3 \cdot 0$ \\
\hline
\end{tabular}

*Approximate extension (m) judged by $x$-ray and sigmoidoscopy. CDAI = Crohn's disease activity index. ${ }^{14}$

S-oroso $=$ Serum-orosomucoid value, normal range: $0 \cdot 7-1 \cdot 3 \mathrm{~g} / 1$. asc $=$ ascendens.

tot $=$ total.

index $(\mathrm{CDAI})^{14}$ of $>200$. These and other pretreatment characteristics of the patients are presented in Table 1. Six healthy volunteers (four men and two women, aged 22-42 yr) from the medical staff were control subjects.

Metronidazole was given orally in the same dose to patients and controls, $400 \mathrm{mg}$ twice daily with one exception, case 5 , who had a reduced dosage $(200 \mathrm{mg}$ in the morning and $400 \mathrm{mg}$ in the evening) because of low body weight $(<40 \mathrm{~kg})$. The control subjects were "treated" for 2 wk and the patients had had the drug from one week to six months at the time for sampling faeces and plasma for estimation of metronidazole concentrations. Cases 1, 2, and 6 and control subjects $A, B$, and $E$ had been treated with sulphasalazine before metronidazole while the others had been without any treatment for at least one month.

\section{PLASMA AND FAECAL SAMPLES}

Faecal samples were collected before treatment, and at various time intervals, as indicated in Table 2, during the period metronidazole was given. The samples were taken 6-8 $\mathrm{h}$ after the intake of the tablets and processed in the laboratory within $30 \mathrm{~min}$ after stool delivery. Venous blood samples were obtained in heparinised test tubes immediately after the collection of faecal samples. After centrifugation, plasma was decanted and stored in glass tubes at $-20^{\circ} \mathrm{C}$ until assayed. All samples were coded and read blindly by the investigator.

\section{ASSAYS OF METRONIDAZOLE}

\section{Faeces}

Upon arrival at the laboratory a spoonful of faeces was weighed in a preweighed plastic tube with screw cap. It was stored at $-20^{\circ} \mathrm{C}$ for 1-7 days and then dried in a freeze dryer (Spedivac Model 5 PS, Crawley, Sussex, England) overnight and re- weighed for dry weight estimation. The freeze-dried specimen was dissolved in $\mathbf{0} \cdot 1 \quad M$ carbonate-o bicarbonate buffer pH 9. Liquid chromatography(LC) based on a reverse phase system and ultraviolet light detection ${ }^{15}$ was used to determine metronidazole concentrations. The minimum detection level was$0.025 \mathrm{mg} / \mathrm{l}$.

\section{Plasma}

Metronidazole in plasma was estimated by $\mathrm{LC}$, andk also by a biological assay (BA) with the use of an agar diffusion method ${ }^{16}$ with Clostridium perfringen: as indicator strain. The method was slightly modifiec $B$ and paper discs were used instead of wells in the agaf plates.

\section{BACTERIOLOGICAL PROCEDURES}

All stool specimens were cultured by curren techniques to exclude infections with Campylobacter, Salmonella, Shigella, and Yersinia. Quantitative ands qualitative bacteriological analyses followed the procedures described elsewhere. ${ }^{11}$ Briefly, a loop fulp of faeces (approximately $0.2 \mathrm{~g}$ ) was weighed in a sterile preweighed gassed-out glass test tube contain? ing glass beads, and diluted with prereduced peptones yeast broth under oxygen-free gas flow $(10 \%$. hydrogen in carbon dioxide) to a concentration of $0.1 \mathrm{~g}$ faeces per $\mathrm{ml}$. The sample was mixed in the tube to a macroscopically homogenous suspension which was serially diluted in tenfold dilutions from $10^{-\mathrm{E}}$ to $10^{-9}$ in peptone yeast broth under gas flow From each dilution $0.1 \mathrm{ml}$ was plated on Columbiep blood agar and Drigalski agar plates and incubatec at $36^{\circ} \mathrm{C}$ for 2 days for total aerobes and Entero? bacteriaeceae; and on freshly prepared brain hearto infusion agar (BHIA) for total anaerobes; BHI with neomycin and vancomycin for anaerobic Gram? negative rods; and BHIA with lysed cow blood witk kanamycin and vancomycin for Bacteroides spp.18 
Table 2 Details of laboratory and clinical findings during treatment with metronidazole of patients with Crohn's disease and healthy individuals

\begin{tabular}{|c|c|c|c|c|c|c|c|c|c|}
\hline \multirow[t]{3}{*}{ Subjects } & \multirow{3}{*}{$\begin{array}{l}\text { Treatment } \\
\text { duration } \\
\text { (months) }\end{array}$} & \multirow{3}{*}{$\begin{array}{l}\text { Diarrhoea } \\
\text { frequency }\end{array}$} & \multirow{3}{*}{$\begin{array}{l}C D A I \\
\text { (active } \\
\text { disease } \\
>100 \text { ) }\end{array}$} & \multirow{3}{*}{$\begin{array}{l}\text { S-oroso } \\
(\mathrm{g} / \mathrm{l}) \\
\text { (active } \\
\text { disease } \\
>1.5 \mathrm{~g} / \mathrm{l})\end{array}$} & \multicolumn{4}{|c|}{ Concentration of metronidazole } & \multirow{3}{*}{$\begin{array}{l}\text { Bacteroides } \\
(C F U / g) \\
\text { wet weight } \\
\text { log values }\end{array}$} \\
\hline & & & & & \multicolumn{2}{|l|}{ Plasma } & \multicolumn{2}{|l|}{ Faeces $(L C)$} & \\
\hline & & & & & $\begin{array}{l}B A \\
(m g / l)\end{array}$ & $\begin{array}{l}L C \\
(m g / l)\end{array}$ & $\begin{array}{l}\text { Wet weight } \\
(m g / g)\end{array}$ & $\begin{array}{l}\text { Dry weight } \\
(\mathrm{mg} / \mathrm{g})\end{array}$ & \\
\hline \multicolumn{10}{|l|}{ Patients } \\
\hline 1 & 4 & 0 & 0 & 0.8 & 15 & 12 & NF & NF & NF \\
\hline \multirow[t]{2}{*}{2} & 1 & 0 & 2 & $1 \cdot 0$ & 10 & 11 & NF & NF & NF \\
\hline & 4 & 0 & -2 & 0.9 & 5 & 3 & NF & NF & NF \\
\hline \multirow[t]{2}{*}{3} & 3 & 0 & 30 & $1 \cdot 2$ & 10 & 9 & 1 & 9 & NF \\
\hline & 6 & 0 & 20 & 1.0 & 14 & 6 & NF & NF & NF \\
\hline \multirow[t]{2}{*}{4} & 1 & 0 & 39 & 0.8 & 30 & 20 & 4 & 26 & NF \\
\hline & 4 & 0 & 15 & 0.8 & 12 & 23 & NF & NF & NF \\
\hline \multirow[t]{2}{*}{5} & 1 & 0 & 76 & $1 \cdot 7$ & 8 & 9 & 9 & 67 & NF \\
\hline & 4 & 0 & 73 & $1 \cdot 7$ & 7 & 15 & 12 & 96 & NF \\
\hline \multirow[t]{3}{*}{$6^{*}$} & $0 \cdot 25$ & 5 & 144 & 1.9 & 13 & 14 & 5 & 53 & NF \\
\hline & 1 & 5 & 125 & $2 \cdot 0$ & 12 & 13 & 9 & 72 & NF \\
\hline & 3 & 3 & 31 & $1 \cdot 2$ & 9 & 14 & 5 & 45 & NF \\
\hline $7 *$ & 0.25 & 6 & 311 & $4 \cdot 0$ & 11 & 12 & 8 & 57 & NF \\
\hline \multirow[t]{2}{*}{$8^{*}$} & 0.25 & 8 & 214 & $2 \cdot 7$ & 7 & 8 & NF & NF & 9.0 \\
\hline & 3 & 7 & 223 & $1 \cdot 3$ & 8 & 6 & 1 & 10 & NF \\
\hline $9 *$ & $0 \cdot 25$ & 4 & 200 & $2 \cdot 4$ & $\begin{array}{l}16 \\
12 \cdot 1\end{array}$ & $\begin{array}{c}13 \\
\bar{x}=11.6\end{array}$ & 23 & 154 & NF \\
\hline \multicolumn{10}{|l|}{ Controls } \\
\hline A & 0.5 & & & & 7 & 5 & NF & NF & $9 \cdot 5$ \\
\hline B & 0.5 & & & & 10 & 7 & NF & NF & 9.9 \\
\hline C & 0.5 & & & & 10 & 9 & NF & NF & $10 \cdot 0$ \\
\hline D & 0.5 & & & & 15 & 9 & NF & NF & $8 \cdot 8$ \\
\hline $\mathbf{E}$ & 0.5 & & & & 23 & 7 & NF & NF & $8 \cdot 3$ \\
\hline $\mathbf{F}$ & 0.5 & & & & 13 & 8 & NF & NF & 10.0 \\
\hline & & & & $\overline{\mathbf{x}}$ & 13.0 & $\overline{\mathrm{x}}=$ & & & \\
\hline
\end{tabular}

* = patients with active disease.

$\mathbf{B A}=$ bioassay.

LC = liquid chromatography.

CFU = colony forming units.

CDAI = Crohn's disease activity index.

$\mathrm{S}$-oroso $=$ serum-orosomucoid value, normal range: $0 \cdot 7-1 \cdot 3 \mathrm{~g} / 1$.

$\bar{X}=$ mean, calculated from mean values for each patient.

$\mathrm{NF}=$ not found $=<0.025 \mathrm{mg} / \mathrm{l}$ (LC)

$<10^{5} \mathrm{CFU} / \mathrm{g}$ (Bacteroides).

The plates for anaerobes were incubated anaerobically (steel jars with palladium catalysts, evacuated and filled with $6 \% \mathrm{CO}_{2}$ in hydrogen) at $36^{\circ} \mathrm{C}$ for 6 days. Colonies growing in the aerobic atmosphere were identified and denominated according to Cowan and Steele. ${ }^{18}$ The strict anaerobes were characterised according to instructions by Holdeman et al. ${ }^{19}$ except for the fermentation tests which were performed with the Minitek system (Miniaturized Microorganism Differentiation System, BBL).

\section{STATISTICAL ANALYSES}

The plasma concentration studies were analysed with Student's $t$ test. For the comparison of the measurement methods, the $t$ test for matched pairs ${ }^{20 a}$ was applied and for the test group differences the $t$ test for independent samples. ${ }^{20 b}$ In the faecal concentration studies the nature of the data required a distribution-free test, the Wilcoxon rank sum test, ${ }^{20 c}$ in the comparison of group differences. In all analyses the mean values for each patient were used. For each test two-sided $p$ values are reported.

\section{Results}

\section{PLASMA CONCENTRATIONS OF} METRONIDAZOLE

The concentrations of metronidazole in plasma of the treated patients and controls are shown in Table 2. In the patients the concentrations varied between 5 and $30 \mathrm{mg} / \mathrm{l}$ with the BA method, and between 3 and $23 \mathrm{mg} / \mathrm{l}$ with LC. In the healthy subjects corresponding values were 7 to $23 \mathrm{mg} / \mathrm{l}$ with the BA method and between 5 and $9 \mathrm{mg} / \mathrm{l}$ with LC, respectively. There was an almost significant difference between the two measurement methods $(p=0.07)$. The observed difference was, however, almost entirely due to the control group with its low $\mathrm{LC}$ values. In accordance with this result the group difference between patients and controls was just significant with respect to the 
LC values $(p=0.05)$ but not significant with respect to the BA values $(p>0.50)$.

FAECAL CONCENTRATIONS OF

METRONIDAZOLE

Metronidazole could not be detected in any of the faecal specimens from the treated healthy subjects. Low concentrations (1-4 mg/l wet weight) of metronidazole were found in two out of seven samples in patients 1-4 who were in remission (CDAI $<50$ and s-orosomucoid values $<1 \cdot 3 \mathrm{~g} / \mathrm{l}$ ). The concentrations varied between $1-23 \mathrm{mg} / \mathrm{l}$ in six out of seven samples in cases 6-9 who had active disease (CDAI $>100$ and s-orosomucoid values $>1.5 \mathrm{~g} / \mathrm{l}$ ). Case 5 with a CDAI of $73-76$ and $\mathrm{s}$-orosomucoid value of $1.7 \mathrm{~g} / \mathrm{l}$ had concentrations of 9 and $12 \mathrm{mg} / \mathrm{l}$ in specimens taken three months apart. The means of the metronidazole concentrations per gram wet faeces were $0.6 \mathrm{mg} / \mathrm{l}$ in cases 1.4 and 9.5 $\mathrm{mg} / \mathrm{l}$ in cases 6-9. There are statistically significant differences between the patients and controls $(p<0.01)$ and also between the patients in remission and those with active disease $(\mathrm{p}<0.05)$.

The concentrations of metronidazole related to dry weight were in most of the patients almost 10 times higher than per gram wet weight, due to a high water content of the stools in patients with Crohn's disease.

BACTERIOLOGICAL FINDINGS

The total counts of anaerobic bacteria before metronidazole treatment (colony forming units (CFU) per gram wet weight faeces, log values) ranged between 9.6 and 10.7 CFU/g in eight of the patients. In case 6 no Bacteroides spp could be found-that is, $<5.0 \mathrm{CFU} / \mathrm{g}$. The corresponding concentrations for the healthy subjects were 9.4 and $10.5 \mathrm{CFU} / \mathrm{g}$. The total counts of aerobes were in all subjects 1-3 log below those of the anaerobes. Bacteroides spp concentrations between 9.3 and $10.0 \mathrm{CFU} / \mathrm{g}$ were obtained in all control subjects and in all the patients except case $2(5 \mathrm{CFU} / \mathrm{g})$ and $6(<5 \mathrm{CFU} / \mathrm{g})$.

The total counts of aerobic, anaerobic bacteria, and of Escherichia coli, the predominant aerobe, were not significantly changed during treatment as also earlier reported.10 11 The concentrations of Bacteroides spp, the predominant anaerobe, were unchanged in the control subjects. In eight of nine patients Bacteroides spp could not be isolated during treatment. Case 8 was an exception with $9 \cdot 0 \mathrm{CFU} / \mathrm{g}$ after one week of treatment, but three months later the Bacteroides spp concentration was below the detection level ( $<5 \cdot 0 \mathrm{CFU} / \mathrm{g}$ ).

\section{Discussion}

When investigating concentrations of metronidazole in plasma and faeces the pharmacokinetic properties of the drug must be recognised. However, only $\underline{\underline{\sigma}}$ limited information is available from studies in man and animals. After oral or rectal administration, plasma metronidazole peak values were reached $\overline{0}$ within $3 \mathrm{~h}$ and $8 \mathrm{~h}$ respectively. The concentrations fell with a mean half-life of 6-10 h. ${ }^{16} 2122$ From $\frac{}{5}$ experiments in rats, Populaire ${ }^{23}$ concluded that the $\stackrel{\mathbb{Q}}{\mathscr{Q}}$ drug was absorbed in the stomach or the proximal on

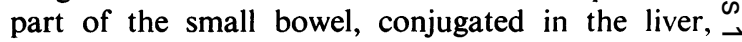
excreted by bile, deconjugated and reabsorbed in ? caecum and colon. In contrast, Ings et al. ${ }^{24}$ found the $\overrightarrow{\vec{\omega}}$ enterohepatic circulation to be low and concluded $\stackrel{\omega}{\stackrel{\omega}{\rho}}$ that after absorption, metronidazole and its metabolites were secreted directly through the bowel $\omega$ mucosa. The renal pathway was the major route of + elimination both in the rat $^{24}$ and man. ${ }^{25}$

In our study metronidazole was detected in faeces of in most patients with Crohn's disease but not in 0 faeces of any healthy individuals. It is well known that Bacteroides spp are extremely sensitive to $ᄃ$ metronidazole. ${ }^{26}$ Our findings showed a significant $\frac{5}{5}$ reduction of species belonging to this genus in the faeces of these patients but not in the healthy $\infty$ individuals as demonstrated in this and previous. studies. ${ }^{10} 11$

It was interesting to note that the patients with active disease had higher faeces metronidazole concentrations than those with a quiescent disease. One can only speculate on the reason for this $\stackrel{\square}{\mathbb{Q}}$ difference. The patient with the highest faecal $\overrightarrow{\vec{A}}$ metronidazole concentration was found to have an $\frac{\circ}{3}$ extensive colon involvement of the disease and a bothersome diarrhoea, both of which might contri-7 bute to a more rapid bowel transport. However, Crohn's disease is also an exudative inflammatory? bowel disease in which the exudation increases with $\frac{5}{3}$ the degree of inflammation and the extent of the disease. It can be noted from Table 2 that faeces $ᄋ$ metronidazole concentrations were high in six out of seven faecal samples from patients with s-orosomu-은 coid values of more than $1.55 \mathrm{mg} / \mathrm{l}$ in comparison to $>$ one out of nine patients with lower s-orosomucoid concentrations. However, these latter patients had no N apparent diarrhoea and they had involvement of ileum and the ascending colon only (Table 1). 0 Populaire $^{23}$ proposed that metronidazole was $\mathbb{N}^{2}$ reabsorbed in the colon, and these latter patients might therefore have this ability in the healthy parto of their colon and rectum. The appearance of $\mathbb{\infty}$ metronidazole in faeces might therefore be due to $\stackrel{?}{?}$ rapid bowel transit, the degree of inflammation, the $\underset{T}{T}$ extent of the disease, increased exudation, decreased $\frac{\vec{D}}{\vec{D}}$ reabsorption, or some combination of these factors. $\stackrel{\mathbb{Q}}{\stackrel{9}{\oplus}}$

The total counts of Bacteroides spp were not $\stackrel{\mathbb{Q}}{\mathscr{Q}}$ significantly changed in any of the healthy individuals 
and in none of them was metronidazole detected in the faeces. In contrast, a few of the patients had significantly decreased Bacteroides spp counts despite the absence of metronidazole in the faeces. In view of the possible mechanisms discussed above, metronidazole might have been excreted in the inflamed areas, then acted on the Bacteroides spp, and then was reabsorbed in the other part of the colon.

The plasma metronidazole concentrations in the healthy individuals, as measured by the LC method, varied between $5-8 \mathrm{mg} / \mathrm{l} 6-8 \mathrm{~h}$ after oral administration which is in close agreement with the findings by Houghton et al. ${ }^{21} \mathrm{~A}$ much wider range was obtained in the patients with Crohn's disease as compared with the healthy individuals. The difference between the obtained levels of the two groups was nearly significant ( $p=0.05$ ). However, the estimations by the LC method gave significantly lower values than the bioassay method in the healthy individuals while the two methods did not significantly differ in the patients. These findings are of some interest since the LC method, being a chromatographical method, detects the parent substance whereas the BA method measures biologically active metabolites as well. ${ }^{26}$ The renal function in the patients and the healthy individuals were similar and the observed differences might therefore indicate other pharmacokinetic dissimilarities in the two groups.

We wish to thank AB Leo, Helsingborg, Sweden for the research grants to this study. We appreciate helpful discussions and advice by Assist Prof D Danielsson and Prof A Rosén. For technical assistance we are indebted to Mrs $\mathrm{K}$ LanbeckVallén, Miss M Karlsson, Mrs U Larsson, and Mrs B Willny-Cederberg.

\section{References}

${ }^{1}$ Cosar C, Julou L. Activity of 1-(2-hydroxyethyl)-2-methyl5-nitroimidazole (RP 8823) in experimental Trichomonas vaginalis infections. Annales de I'institut Pasteur 1959; 96:238-41.

${ }^{2}$ Shinn DLS. Metronidazole in acute ulcerative gingivitis. Lancet $1962 ; \mathrm{i}: 1191$.

${ }^{3}$ Tally FP, Sutter VL, Finegold SM. Metronidazole versus anaerobes-in vitro data and initial clinical observations. Calif Med 1972;117:22-6.

${ }^{4}$ Dornbusch K, Nord C-E. In vitro effect of metronidazole and tinidazole on anaerobic bacteria. Med Microbiol Immunol 1974;160:265-7.

${ }^{5}$ Brogden RN, Heel RC, Speight TM, Avery GS. Metronidazole in anaerobic infections: A review of its activity pharmacokinetics and therapeutic use. Drugs 1978;16: 387-417.

6 Willis AT, Bullen CL, Ferguson IR, et al. Metronidazole in the prevention and treatment of Bacteroides infections in gynaecological patients. J Antimicrob Chemother 1975; 1:393-401.

7 Ursing B, Kamme C. Metronidazole for Crohn's disease. Lancet 1975; ; :775-7.

${ }^{8}$ Allan R, Cooke WT. Evaluation of metronidazole in the management of Crohn's disease. Gut 1977;18:422.

${ }^{9}$ Blichfeldt P, Blomhoff JP, Myhre E, Gjone E. Metronidazole in Crohn's disease. A double blind cross-over clinical trial. Scand J Gastroenterol 1978;13:123-7.

${ }^{10}$ Krook A, Danielsson D, Kjellander J, Järnerot G. The effect of metronidazole and sulphasalazine on the faecal flora in patients with Crohn's disease. Scand J Gastroenterol 1981; (in press).

${ }^{11}$ Krook A. Effect of metronidazole and sulphasalazine on the normal human faecal flora. Scand $J$ Gastroenterol 1981 ; (in press).

12 Arabi Y, Dimock F, Burdon DW, Alexander-Williams J, Keighley MRB. Influence of neomycin and metronidazole on colonic microflora of volunteers. J Antimicrob Chemother 1979;5:531-7.

${ }^{13}$ Richards GK, Dion YM, Wink I, Hinchey EJ. Effect of oral and parenteral metronidazole on the incidence of postoperative wound infection in elective colonic surgery. In: Royal Society of Medicine, International Congress Symposium Series No 18, Metronidazole. London: Academic Press, 1979;161-5.

${ }^{14}$ Best WR, Bectel JM, Singleton JW, Kern F. Development of a Crohn's disease activity index. Gastroenterology 1976;70:439-44.

${ }^{15}$ Lanbeck K, Lindström B. Determination of metronidazole and tinidazole in plasma and feces by high-performance liquid chromatography. J Chromatogr 1979;162:117-21.

${ }^{16}$ Melander A, Kahlmeter G, Kamme C, Ursing B. Bioavailability of metronidazole in fasting and non-fasting healthy subjects and in patients with Crohn's disease. Eur J Clin Pharmacol 1977;12:69-72.

17 Blair JE, Lenette EH, Truant JP. Manual of clinical microbiology. Baltimore: American Society for Microbiology, 1970:268-9.

18 Cowan ST, Steele KJ. Manual for the identification of medical bacteria. London: CUP, 1974.

19 Holdeman LV, Cato EP, Moore WEC. Anaerobic Laboratory Manual 4th ed. Blacksburg Virginia: Virginia Polytechnic Institute and University, 1977.

${ }^{20}$ Colton T. Statistics in medicine. Boston: Little, Brown, and Co, 1974: (a) 131-6 (b) 136-42 (c) 221-3.

${ }^{21}$ Houghton GW, Thorne PS, Smith J, et al. The pharmacokinetics of intravenous metronidazole. In: Royal Society of Medicine. International Congress and Symposium Series No 18, Metronidazole. London: Academic Press, 1979:35-40.

${ }^{22}$ Houghton GW, Thorne PS, Smith J, Templeton R. Plasma metronidazole concentrations after suppository administration. In: Royal Society of Medicine. International Congress and Symposium Series No 18, Metronidazole. London: Academic Press, 1979:41-4.

23 Populaire P, Benazet F, Pascal S, Lebreton G, Decouvelaere B, Guillaune L. Circulation et sort du métronidazole dans le tractus digestif chez le rat aprés administration par voie orale absorption du métronidazole per les muqueuses digestive. Thérapie $1971 ; 26: 581-94$.

${ }^{24}$ Ings RMJ, McFadzean JA, Ormerod WE. The fate of metronidazole and its implications in chemotherapy. Xenobiotica 1975;5:223-5.

${ }^{25}$ Schwartz DE, Jeunet F. Comparative pharmacokenitic studies of ornidazole and metronidazole in man. Chemotherapy 1976;22:19-29.

26 Chow AW, Dominick B, Lucien G. Susceptibility of obligate anaerobes to metronidazole: An extended study 
of 1054 clinical isolates. In: Royal Society of Medicine. Requests for reprints to: Dr A Krook, Department of International Congress and Symposium Series No 18, Clinical Microbiology, Central County Hospital, S-701 85 Metronidazole. London: Academic Press, 1979:161-5.

Örebro, Sweden. 